\title{
Analysis of and Suggestions Regarding the Current Status of Utilization and Disposal for General Industrial Solid Wastes in Chongqing
}

\author{
Qiang Liu ${ }^{1, ~ a, ~ J i a l i e ~ L i u ~}{ }^{1, b}$, Manli Zhang ${ }^{1, ~ c}$ and Shuiwen Yang ${ }^{1, d^{*}}$ \\ ${ }^{1}$ Chongqing Solid Waste Management Center, 401147, China \\ a 50474783@qq.com, b624440350@qq.com, \\ c32310231@qq.com , d yangshuiwen@126.com
}

\begin{abstract}
Keywords: General industrial solid wastes; Utilization and disposal; Environment management; Analysis of current status
\end{abstract}

\begin{abstract}
Objective: The object of this study is to point out some problems existing in the utilization and disposal of general solid wastes and environment management in Chongqing. Methods: The present status of the utilization and disposal of general industrial solid wastes there for five consecutive years (2011-2015) were analysized. Results: The author offers control suggestions for general industrial solid wastes from the perspectives of encouraging technology development, accelerating treatment ability, conducting investigation and improvement of current status and building platform for the exchanging solid waste targeting at the production features, as well as the current status of utilization and disposal, and the requirements of environment management of general industrial solid wastes in Chongqing. Conclusion: These provide a reference for the environment management of general industrial solid wastes in Chongqing.
\end{abstract}

\section{Introduction}

In recent years, the economy of Chongqing has grown rapidly, and its economic growth rate is currently at the forefront of the country [1]. The basic industries there, including mining, geothermal electricity production, metal smelting and petrochemical industries, have great contributions to economic development. At the same time, these industries also produce large amounts of general industrial solid wastes, including fly ash, slag, coal gangue, desulphurization gypsum, phosphogypsum, smelting waste slag, and tailings [2-3]. Due to the restrictions of the historical factor, the utilization of technology and environment management, as well as a large amount of general industrial solid wastes, high disposal cost and great difficulty in management, the pollution control of general industrial solid waste cannot be settled, thereby resulting in land resource embezzlement and environmental pollution, and especially in some regions the pollution problems of specific pollutants for general industrial solid waste are particularly prominent [4-6].

What we must determine and resolve are the problems of how to decrease the production of general industrial solid waste, improve its utilization rate, decrease the number of landfills, reduce and control environmental pollution, and lower pollution treatment cost. Therefore, this paper proposes countermeasures and measures regarding the pollution control of general industrial solid waste, through deep analysis of the current status of production, utilization and disposal of general industrial solid wastes in Chongqing. This is expected to provide a basis for the environment management of Chongqing and other regions' general industrial solid wastes.

\section{Current Status of the Utilization and Treatment of Chongqing General Industrial Solid Wastes}

\section{Current Status of Production}

In 2015, 28,279,900 tons of general industrial solid wastes were produced in Chongqing, including fly cash $(23.19 \%)$, slag $(20.85 \%)$, coal gangue $(14.55 \%)$, and desulphurization gypsum $(8.68 \%)$. The combined output of these main general industrial solid wastes, which are mainly produced from power generation and supply, coal mining and washing, nonmetallic mineral manufacturing industry, 
cement manufacturing industry and chemical materials and chemistry manufacturing industry, accounts for $77.47 \%$ of the gross production of the city's general industrial solid wastes. The 2011-2015 output of Chongqing's main general industrial solid wastes is shown in Table 1 [2].

Table 1 2011-2015 output of Chongqing main general industrial solid wastes Unit: 10,000 tons

\begin{tabular}{|c|c|c|c|c|c|c|c|}
\hline Year & $\begin{array}{c}\text { Gross output of } \\
\text { general industrial } \\
\text { solid wastes }\end{array}$ & $\begin{array}{c}\text { Coal } \\
\text { gangue }\end{array}$ & Fly ash & Slag & $\begin{array}{c}\text { Desulphuriz } \\
\text { ation } \\
\text { gypsum }\end{array}$ & Tailings & $\begin{array}{c}\text { Other } \\
\text { wastes }\end{array}$ \\
\hline 2011 & 3299.18 & 309.47 & 1017.77 & 659.73 & $/$ & 344.00 & 392.25 \\
\hline 2012 & 3114.89 & 353.32 & 839.48 & 641.38 & $/$ & 339.22 & 306.27 \\
\hline 2013 & 3161.80 & 351.73 & 898.47 & 678.07 & $/$ & 246.07 & 277.49 \\
\hline 2014 & 3067.78 & 308.78 & 815.92 & 661.73 & 228.87 & $/$ & 345.77 \\
\hline 2015 & 2827.99 & 411.39 & 655.70 & 589.61 & 245.46 & $/$ & 288.78 \\
\hline
\end{tabular}

As shown in Table 1, the output of Chongqing's general industrial solid wastes was reduced from 2011 to 2015 with a small decreasing amplitude. Among the general industrial solid waste on the top of output, the output of tailings and fly ash were reduced year by year, while that of coal gangue increased. However, the proportion changed little, which is related to the national economy in recent years, as well as the optimization and adjustment industrial structure in Chongqing. In addition to the main industrial solid wastes, the utilization and disposal of electrolytic manganese residue and phosphogypsum with large outputs cannot be ignored. Therefore, the utilization, disposal difficulties and supervision pressure of Chongqing general industrial solid wastes still exist. [8-9]

\section{Current Status of Utilization and Treatment}

In 2015, 28,279,900 tons of general industrial solid wastes were produced in Chongqing, among which the utilization capacity was $23,816,000$ tons, the disposal capacity was $3,826,600$ tons and the storage capacity was 561,500 tons. The utilization rate of Chongqing general industrial solid waste shows a growth trend, but the rate in recent years is about 84\%, which is no major breakthrough, and this reached a bottleneck [2].The 2011-2015 utilization of Chongqing's general industrial solid waste is shown in Table 2 [2].

Table 22015 Utilization of Chongqing's general industrial solid wastes

\begin{tabular}{cccc}
\hline $\begin{array}{c}\text { Classification of industrial } \\
\text { solid waste }\end{array}$ & $\begin{array}{c}\text { Output } \\
(10,000 \text { tons })\end{array}$ & $\begin{array}{c}\text { Utilization } \\
(10,000 \text { tons })\end{array}$ & Utilization rate (\%) \\
\hline Fly ash & 655.70 & 625.37 & 95.37 \\
\hline Slag & 589.61 & 563.41 & 95.55 \\
\hline Coal gangue & 411.39 & 387.45 & 94.18 \\
\hline Desulphurization gypsum & 245.46 & 227.47 & 92.67 \\
\hline Other wastes & 288.78 & 238.05 & 82.43 \\
\hline
\end{tabular}

As can be seen from Table 2, the utilization rate of the main general industrial solid wastes in Chongqing in 2015 was greater than 90\%, among which the utilization of slag was $95.55 \%$. In recent years, the utilization of general industrial solid waste has had no major breakthrough, which is related to the low quality of valuable material in wastes, including phosphogypsum, tailing and smelting waste slag, as well as high utilization cost, low effectiveness and heavy environment pollution [3]. Coal gangue is applied to electricity generation and building in Chongqing, and fly coal is used as a replacement for cement and applied to buildings. Slag is used as a replacement for cement, and smelting waste slag is used to produce cement. However, landfills are still the main disposal means. Therefore, one of the key points of the environment management of general industrial solid wastes in Chongqing is to develop and generalize the utilization technology of general industrial solid waste. 


\section{Existing Problems}

In recent years, the utilization rate of the main general industrial solid wastes is stable at over $90 \%$, according to the utilization and disposal and current status of general industrial solid wastes in Chongqing. However, some general industrial solid wastes are still not used effectively, and the risks of environment pollution for stockpiling or landfills has yet to be eliminated completely, due to the limitations of history, environment management and utilization technology. Environmental safety problems still exist, especially in some select regions.

Some utilization technologies of general industrial solid wastes have yet to be perfected, and it is difficult for the utilization products to meet the market requirements. Although the utilization rate of the main general industrial solid wastes in Chongqing reaches $90 \%$, for some general industrial solid wastes, such as phosphogypsum, smelting waste slag and electrolytic manganese residue [7-10], and other wastes with small amounts, their utilization is limited in experimentation and exploration, due to the limitations of utilization technology, production cost and marketing concept. In addition, the industrial production scale has not yet to be formed, thus the wastes must be stockpiled or disposed in landfills. Environment pollution hazards are prominent.

The final disposal capability of general industrial solid wastes is insufficient. For the final disposal means of general industrial solid wastes in Chongqing, except for a small number of enterprises which produce equipment for incineration and landfills (not open for business), co-processing equipment in cement kilns and landfills produced in a few industrial parks in districts and counties are only open to the public. Most industrial parks or industrial concentration districts in the city are not equipped with the incineration or landfill equipment for general industrial solid wastes. For general industrial solid wastes with small outputs from many single companies, there are no safe and stable final disposal centers, resulting in large amounts of wastes flowing to the landfills for household waste, or being arbitrarily poured. Therefore, great environment pollution hazards exist.

The information exchange regarding general industrial solid wastes is not open. There are relatively few business units operating with hazardous wastes, and the business capacity and business scope are published periodically by the Environmental Protection Department. The hazardous waste production units and utilization units can exchange information freely. However, for general industrial solid wastes, their production information and information regarding utilization and disposal cannot be exchanged freely. The production and utilization and disposal units of general industrial solid wastes are not the published focuses of legal information, and there are no authoritative platforms for the utilization, disposal and supply information, which are only exchanged by means of industry communication and word of mouth, which hinders the standardized management and safe utilization and disposal of general industrial solid wastes to a certain extent .

\section{Suggestions}

Compared with industrial hazardous wastes, the danger of general industrial solid waste is less significant, yet the output of general industrial solid wastes is large and the range of its production industries and regions is broad. Therefore, performing well in the environment management of general industrial solid wastes is the key to the environment management of general industrial solid wastes throughout Chongqing. Combined with the practical conditions in Chongqing, the environment management of general industrial solid wastes can be strengthened from the aspects of encouraging technology development, accelerating treatment ability, conducting investigation and improvement of current status, and building a platform for the exchanging solid wastes. The specific suggestions are as follows:

Introduce an economic tax policy and encourage the development of economical and feasible utilization technology of general industrial solid wastes. Compared with regular industrial production, the comprehensive utilization of wastes has economical and environmental risks, and is influenced by the market, thus many companies are prudent in their investments. The national and 
local governments must introduce economy and tax policies to encourage the comprehensive utilization of wastes to minimize the economical and market risks undertaken by the companies. Therefore, the companies must be willing to develop advanced comprehensive utilization technology, and produce safe and environmental comprehensive utilization products, so as to improve the utilization rate of wastes and reduce environmental risks.

Plan reasonably and improve the final disposal capacity of general industrial solid wastes. Industrial parks and industrial concentration districts producing general industrial solid wastes shall be equipped with incineration and landfill equipment for general industrial solid wastes, so as to ensure that there are places for the general industrial solid wastes which are not or cannot be utilized temporarily, so as to lower the risk of environmental pollution. Companies producing bulk general industrial solid wastes must be equipped with final disposal facilities for general industrial solid wastes, if no complete and stable utilization measures are in place.

Strengthen the declaration and registration and build a platform for the information exchange of general industrial solid wastes. The declaration and registration of general industrial solid wastes must be strengthened, the waste production units must improve their main responsibility and awareness, and the waste production and direction of utilization and treatment must be declared truthfully, which provides reliable evidence for the decision-making of the environmental protection department. The action of setting up a general industrial solid waste platform provides a publishing platform of authoritative utilization and treatment information for the production units, utilization and disposal units of general industrial solid wastes, spans the channel of information communication, and decreases the disposal cost of general industrial solid wastes and environmental risk [3].

\section{References}

[1] Chongqing Municipal People's Government. 2016 Work Report of Chongqing Municipal People's Government [N]. Chongqing: Chongqing Daily Press, 2016-01-29.

[2] Chongqing Environmental Protection Bureau. Information on Pollution Prevention and Control of Solid Waste in Chongqing in 2011-2015 [R]. Chongqing: Governmental Public Information Service Network of Chongqing Municipal Environmental Protection Bureau, 2012-2016.06.

[3] LY Jiang. Study of Industrial Symbiosis based on Chongqing Municipal Industrial Solid Wastes [D]. Chongqing University, 2010.

[4] YH Zhao et al. Promoting Comprehensive Control of Manganese pollution in "Manganese River Delta" [R] Environment Planning and Policy, 2011, 08.

[5] CX Tao et al. Current Status and Prospect of Comprehensive Utilization for Industrial Solid Wastes Resources [J]. Recourses Economization \& Environmental Protection, 2013, 11.

[6] LN Zhao et al. Producing Characteristics and Control Strategies of China Industrial Solid Wastes [J] Environmental Engineering, 2013, 31 (S1): 464-469.

[7] "Twelfth Five-Year Plan" on Comprehensive Utilization of Bulk Industrial Solid Wastes [J] Sulphuric Acid Industry, 2012, 3: 36.

[8] X Sun et al. Comparative Analysis of Environmental Risk Assessment on Bulk Industrial Solid Wastes Pollution [J] Mining and Metallurgy, 2012, 21(4):97-102.

[9] TY Lu et al. Solid Wastes of Phosphogypsum Produced by Phosphoric Acid Industry and its disposal Status [J]. Anhui Chemical Industry, 2014, 40 (4): 75-78.

[10]HJ Song. Status Analysis of Medical Waste Treatment and Countermeasure Research in Zhengzhou [J]. Environmental Sanitary Engineering, 2014, 22 (2): 56-58. 